\title{
Massive decline of the world's largest king penguin colony at lle aux Cochons, Crozet
}

\author{
HENRI WEIMERSKIRCH ${ }^{\mathbf{1}}$, FABRICE LE BOUARD ${ }^{\mathbf{1 , 2}}$, PETER G. RYAN ${ }^{\mathbf{3}}$ and C.A. BOST ${ }^{\mathbf{1}}$ \\ ${ }^{1}$ Centre d'Etudes Biologiques Chizé, CNRS - Université de la Rochelle, 79360 Villiers en Bois, France \\ ${ }^{2}$ Réserve Nationale des Terres Australes Françaises, TAAF, 97420 Saint Pierre, La Réunion \\ ${ }^{3}$ FitzPatrick Institute of African Ornithology, DST-NRF Centre of Excellence, University of Cape Town, Rondebosch 7701, \\ South Africa \\ henri.weimerskirch@cebc.cnrs.fr
}

\begin{abstract}
King penguins (Aptenodytes patagonicus Miller) are major consumers in the Southern Ocean. The colony at Ile aux Cochons, Iles Crozet, in the southern Indian Ocean was known in the 1980s as the largest king penguin colony and the second largest penguin colony in the world. However, there have not been any recent estimates of this colony. Aerial photographs taken from a helicopter, and satellite images were used to report on changes in the colony and population sizes over the past 50 years. The colony has declined by $88 \%$ over the past 35 years, from $c$. 500000 pairs to 60000 pairs. The possible causes of this decline were explored but no plausible explanation for such an unprecedented decrease in penguin populations was found. The study highlights the use of satellite imagery as a non-invasive technique for population monitoring, and stresses the need for further research on the causes of this alarming trend in this colony.
\end{abstract}

Received 14 December 2017, accepted 23 April 2018

Key words: Aptenodytes patagonicus, satellite image, remote sensing

\section{Introduction}

King penguins (Aptenodytes patagonicus Miller) are major consumers in the Southern Ocean (Guinet et al. 1996). During the breeding season, they mostly eat myctophid fish that are caught in deep waters, mainly in the Polar Frontal Zone (South Georgia: Scheffer et al. (2012), Marion: Pistorius et al. (2017), Crozet: Bost et al. (2015)). Numbers of king penguins have increased throughout the Southern Ocean over the past 50 years (Weimerskirch et al. 1989, 1992, Sanders 2006, Crawford et al. 2009). This increase has been interpreted as a recovery from historical exploitation in the 19th century (Rounsewell \& Copson 1982, Weimerskirch et al. 1992) or change in the functioning of trophic food webs (Guinet et al. 1996). However, their numbers may fluctuate extensively in response to large-scale climatic events such as the Sub-Tropical Indian Dipole and El-Niño Southern Oscillation (ENSO; Le Bohec et al. 2008, Bost et al. 2015). Until now, the Morne du Tamaris Colony, Ile aux Cochons, Iles Crozet, in the southern Indian Ocean, has been known as the largest king penguin colony (Guinet et al. 1995). This colony, discovered and photographed by a cartographic team in 1962, was estimated from surface measurements of the colony and breeding densities to contain more than 300000 pairs of king penguins (Bauer 1963) (Table I). Later estimates from satellite images indicated that it had increased in the surface area occupied, and hosted c. 500000 breeding pairs in 1982-1988 (Guinet et al. 1995). The Morne du
Tamaris colony accounted for a significant proportion of the total consumption by the seabird community in the Indian Ocean at this time (Guinet et al. 1996) and was considered to be the second largest penguin colony in the world (Convey et al. 1999). The monitoring of this immense colony has become a priority for monitoring programmes in the Southern Ocean, especially since the 1997 El-Niño event negatively affected the foraging capacities, and as a result the survival and growth rates, of king penguins on nearby Ile de la Possession, $100 \mathrm{~km}$ to the east of Ile aux Cochons (Bost et al. 2015).

This paper reports on changes in size over the past 50 years at Ile aux Cochons. Satellite imagery and recent photographs taken from helicopters were used to estimate the surface area occupied by the colony and to infer changes in the population size.

\section{Materials and methods}

Ile aux Cochons $\left(67 \mathrm{~km}^{2}\right)$ is one of the three larger islands of the Crozet archipelago located at $46.1^{\circ} \mathrm{S}, 50.2^{\circ} \mathrm{E}$. It is a remote island that is rarely visited. The large king penguin colony is located c. $1.5 \mathrm{~km}$ from the eastern shore of the island on the border of an ancient volcanic cone, the Morne du Tamaris (144 m, Fig. 1).

King penguins breed in large colonies on flat or gently sloping, unvegetated ground, where they are dispersed regularly, at densities of 1.6-2.2 incubating birds per square metre (Bauer 1967, Barrat 1976). Densities of incubating penguins increase only slightly when the 
Table I. Estimates of colony surface area (bare surfaces), surfaces occupied by breeding king penguins, and number of breeding pairs based on 1.6 incubating individuals per square metre (Bauer 1967), based on oblique photographs taken from a helicopter and satellite imagery, for the Ile aux Cochons colony of Morne du Tamaris.

\begin{tabular}{|c|c|c|c|c|c|}
\hline Date & Survey method & Colony area $\left(\mathrm{m}^{2}\right)$ & $\begin{array}{l}\text { Area occupied by } \\
\text { breeding pairs }\left(\mathrm{m}^{2}\right)\end{array}$ & $\begin{array}{l}\text { No. of breeding } \\
\text { pairs }\end{array}$ & Reference \\
\hline End Dec 1962 & Helicopter, vertical & & 198000 & 317000 & Bauer 1967 \\
\hline 15 Feb 1982 & Helicopter, vertical & 314000 & & 502400 & $\begin{array}{l}\text { Institut Géographique National, } \\
\text { Guinet et al. } 1995\end{array}$ \\
\hline 19 Jan 1988 & Spot satellite & 308500 & & 494000 & Guinet et al. 1995 \\
\hline 24 Jan 2005 & WordlView-3 VHR satellite & 223200 & & & \\
\hline 20 Jan 2015 & WorldView-3 satellite & 120549 & 47900 & 76640 & \\
\hline
\end{tabular}

number of incubating birds in a colony increases, as king penguins do not build nests, and disperse, slightly more than one flipper length apart (Barrat 1976). Laying starts in mid-November, with peak numbers of breeding birds being observed in January (Weimerskirch et al. 1992, Descamp et al. 2002).

Published (Bauer 1967, Guinet et al. 1995) and more recent oblique photographs taken from helicopters, and satellite images, were compiled (Table I). In addition to helicopter flights over the Morne du Tamaris colony in 1962 and 1982, flights were carried out from the RS
Marion Dufresne in December 1999 and from the RS Akademik Tryoshnikov on 30 December 2016 during the Antarctic Circumpolar Expedition (ACE; PGR, FL). In addition, high-resolution multispectral satellite images taken in January 2015 and April 2017 from the WorldView-3 VHR satellite were used, with the visible bands $(2 / 3 / 5)$ pan-sharpened to provide $31-\mathrm{cm}$ resolution colour images from Digital Globe (https://www. digitalglobe.com) (Table I).

From satellite images it can be seen that breeding 'patches' occur in bare areas, clearly distinguishable from
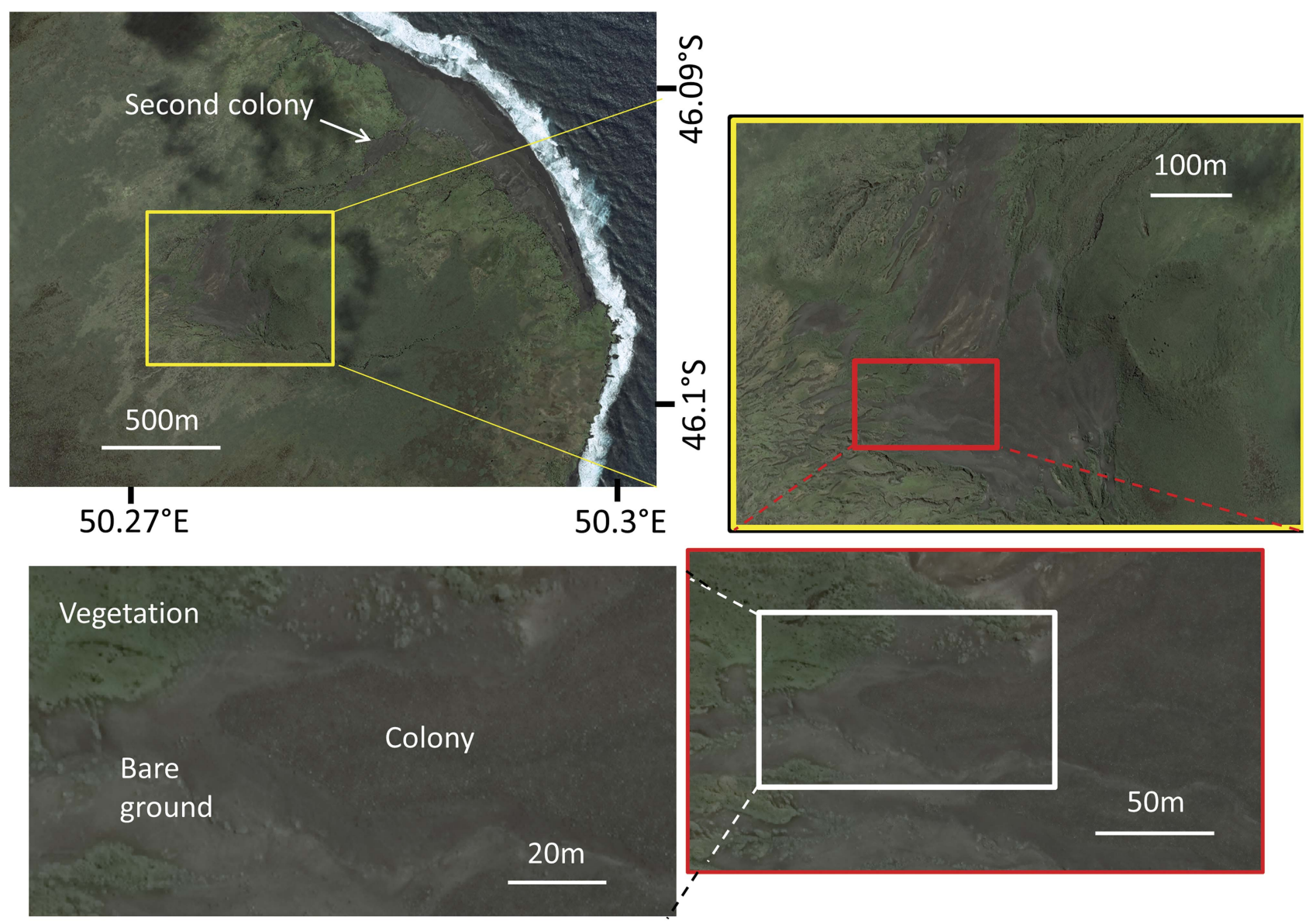

Fig. 1. Satellite images of the Morne du Tamaris king penguin colony at different scales. 
surrounding vegetated areas (Fig. 1). The surface area of the bare ground can be used to estimate the surface area occupied by the colony, provided that breeding birds occupy the entire bare ground (Guinet et al. 1995). However, during recent years, even at peak breeding time in January, nesting birds have not occupied the entire surface area of bare ground (Fig. 1). Thus when possible, with the most recent high-resolution satellite images from 2015 and 2017, both the entire bare surface area and the surface area occupied by breeding penguins were estimated. Surfaces were estimated by importing satellite images into the Quantum GIS geographical information system and outlining the border of the surfaces. The number of breeders was estimated by using the conservative figure of 1.6 pairs per square metre (Bauer 1967).

\section{Results}

A comparison of estimates of the total surface area occupied by the colony of Morne du Tamaris between 1962 and 2017 indicates that areas of bare and occupied surfaces have shrunk by $64 \%$ from their maximum extent in 1982 to a minimum in 2017 (Table I). The total surface area has decreased progressively since 1982 , as shown by surface contour lines in Fig. 2. Recent satellite images show that a large section of the former maximum surface has been re-vegetated rapidly over the last 10 years.

When peak numbers of incubating birds were present the colony occupied only $40 \%$ of the surface available in January 2015, and 32\% in April 2017, when adult birds were brooding late chicks, and large chicks were grouped in crèches. Oblique photographs taken by helicopter confirmed that the colony was occupying a reduced area of bare ground. The 2015 data are considered for comparison with historical counts because this was the period of maximum occupancy of the colony, and the images obtained in 2015 clearly distinguish areas of bare ground from the areas occupied by incubating birds (Table I, Fig. 3). The data from April 2017 cannot be used in the comparison with historical counts, as most of the breeders at this time had left their chicks unattended in crèches (Barrat 1976). Thus, considering that the colony

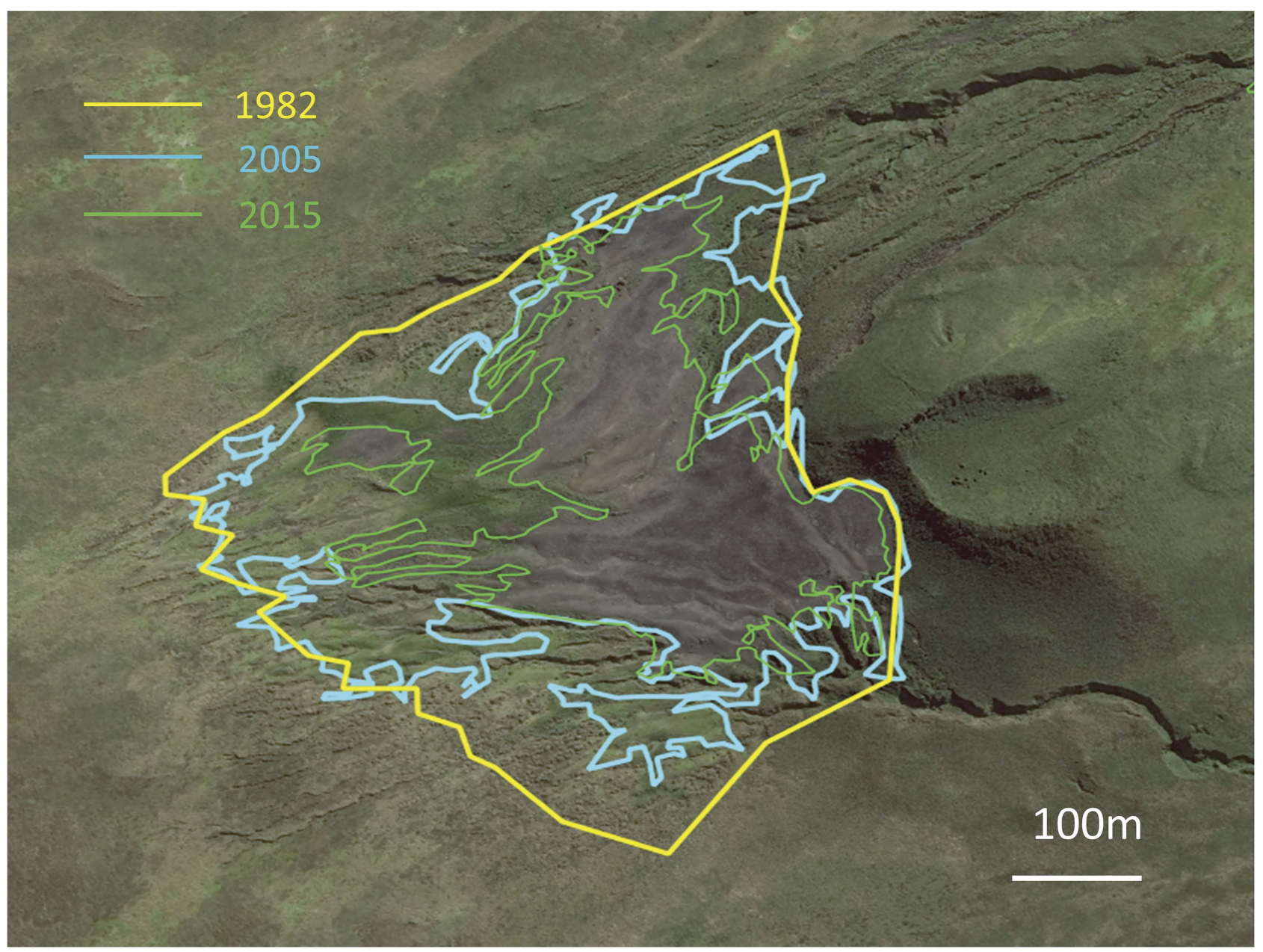

Fig. 2. Contours of the extent of the king penguin colony in 1982 (total bare ground occupied by breeders), 2005 (bare ground) and 2015 (bare ground), applied on the 2015 satellite image. 


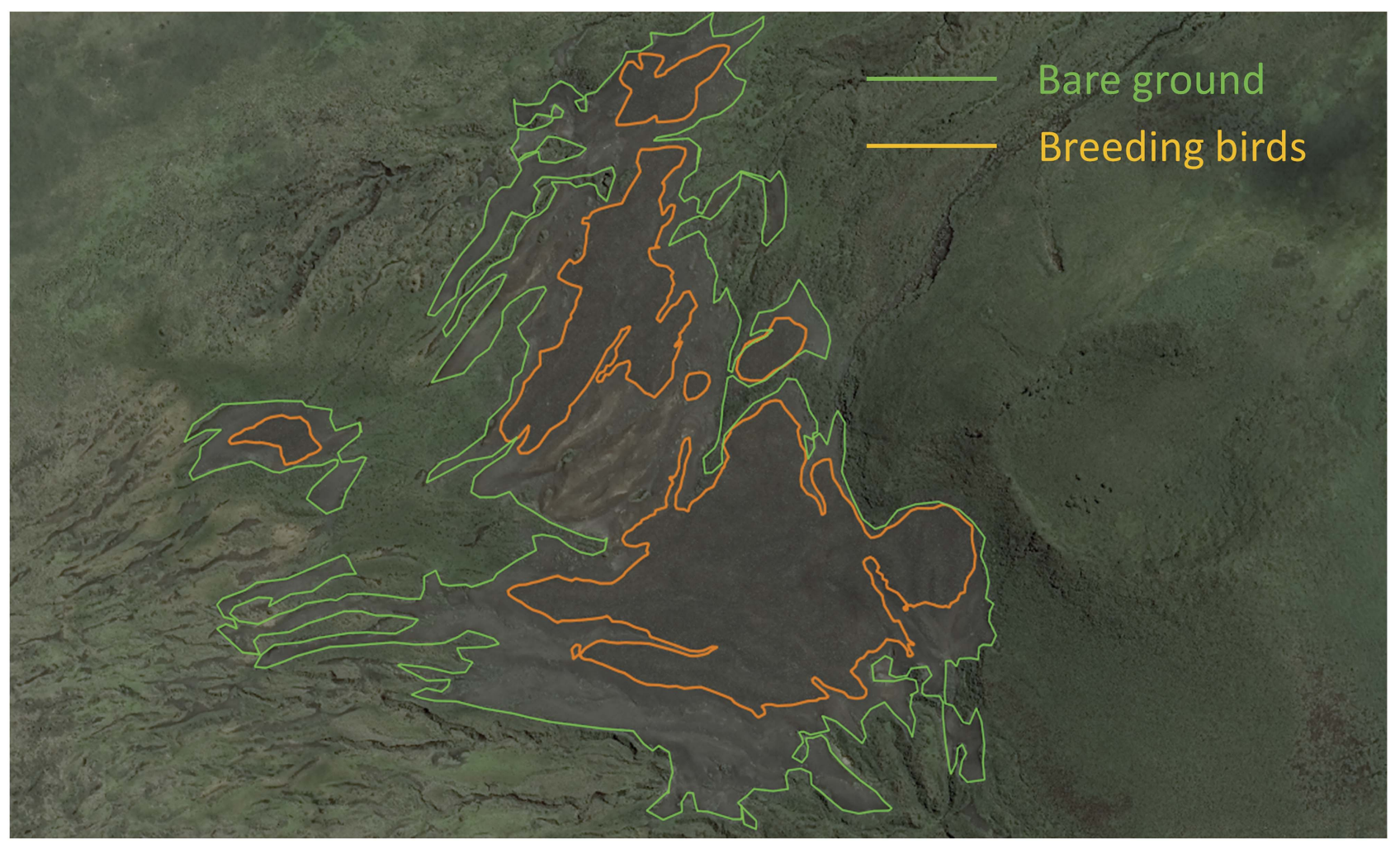

Fig. 3. Colony extent (bare ground, green) and surface area occupied by breeding king penguins (orange) on 24 January 2015.

fully occupied the bare ground in 1982, as indicated by Guinet et al. (1995), the population of king penguins declined by $85 \%$ between 1988 and 2015, from 494000 to 76000 pairs.

A second, smaller, colony of king penguins is located on the path used by penguins between the beach where penguins land and the Morne du Tamaris colony (second colony in Fig. 1). This colony was not mentioned in the previous counts. This colony had an estimated 17500 breeding birds in January 2015 (estimated from surface area occupied by breeding birds), and 14000 breeding birds in late December 2016 (direct count from aerial photographs), $c$. one month before the colony attains peak numbers.

\section{Discussion}

The analysis of recent aerial photographs and satellite imagery shows that the king penguin colony of Morne du Tamaris on Ile aux Cochons has experienced a massive, unexpected decline, decreasing by $85 \%$ over the past 30 years. In the 1980 s, the colony was the second largest penguin colony in the world, after the colony of chinstrap penguins (Pygoscelis antarctica Forster) at Zavodovski Island, South Sandwich Islands (Convey et al. 1999, Boersma \& Borboroglu 2013).
The 1962 estimate of slightly more than 317000 pairs was made from vertical photographs taken from a helicopter, and is considered to be fairly accurate (Bauer 1963). The estimate from the Spot satellite image in 1988 was based on the surface area of the colony, and assumed that breeders occupied all the bare ground at the colony site, which was suggested by helicopter photographs in 1982 (Guinet et al. 1995). As it is not known for certain that the surface was fully occupied, the 494000 breeders in 1988 may be an overestimate, although the bare surface had definitely increased between 1962 and 1982, suggesting an extension of the colony over this time. A low-quality lateral photograph taken in December 1998 suggests that the colony was not at its full extent at this time. The 2005 and especially the 2015 satellite images taken in January were of high quality and allowed the delineation of the bare surface area and of the area occupied by breeders. It showed that in 2005 and 2015, the full extent of the surface occupied by breeders was much smaller than the area of bare surface, associated with the retraction of the surface occupied by breeding birds.

The use of satellite images to monitor penguins is becoming increasingly popular (Guinet et al. 1995, Fretwell et al. 2012, LaRue et al. 2014) and offers the potential to assess and estimate population change in remote regions such as isolated islands in the Crozet 
archipelago. Whereas detection of large colonies is now relatively easy, obtaining population estimates remains challenging and requires making a series of assumptions and ground truthing (LaRue et al. 2014). In contrast to emperor penguins (Aptenodytes forsteri Gray), for which colonies can be detected from guano deposits on the ice (Fretwell \& Trathan 2009) and population estimates are difficult, king penguins breed on bare flat ground, at relatively constant densities. The range of king penguin densities (1.6-2.2 incubating birds $\mathrm{m}^{-2}$ ) (Bauer 1967, Barrat 1976) depends on the ratio of the total number of birds with respect to available bare ground and on the stage of the breeding cycle. In this study the numbers in the period of maximum occupation of the colonies were compared, and a figure of 1.6 individuals $\mathrm{m}^{-2}$ was used for all periods. As a massive decline would be expected to result in a slight decrease in densities over time, using the same minimal densities over time results in a conservative estimate of the extent of decline.

The Morne du Tamaris colony increased between 1962 and 1982 (Guinet et al. 1995), like other king penguin colonies monitored in Iles Crozet (Weimerskirch et al. 1989, 1992). The extensive decline between 1982-88 and 2015-17 on Ile aux Cochons was unexpected, because the monitored colonies elsewhere in the Crozet archipelago (Ile de la Possession) remained stable overall with interannual fluctuations over this period (Bost et al. 2015). King penguin colonies at Marion Island $(900 \mathrm{~km}$ west) and Iles Kerguelen (1200 km east-south-east) have increased since the 1960s (Crawford et al. 2009, Weimerskirch unpublished data), thus the decline of king penguins seems to be a site-specific phenomenon at Ile aux Cochons. The decline appears to be progressive, or at least the bare area occupied by the colony has decreased progressively, with a gradual recovery of the vegetation around the periphery of the colony compared to its maximum extent in 1982.

Several hypotheses might explain the massive decline in this colony. First, the decline occurred from the late 1990s, coinciding with the strong Dipole event in 1997 that affected the foraging capacities of king penguins on Ile de la Possession, the second most important island of Iles Crozet for breeding king penguins, with negative consequences for breeding performance and colony size (Bost et al. 2015). The 1997 event may have affected the population of Ile aux Cochons more severely than other colonies because of stronger density-dependent effects, and the population has not recovered, as has been observed on Ile de la Possession (Delord et al. 2004, Bost et al. 2015).

Second, the decline may have resulted from the partial relocation of the colony. King penguins are relatively faithful to their birthplace and first breeding site (Saraux et al. 2011) and it seems unlikely that adults and young individuals from Ile aux Cochons have a different behaviour than those from other colonies. However, observations from helicopter flights in 2016 noted a smaller colony nearer to the beach, on the penguins' access route to the large colony. This colony was recorded for the first time on the 2005 satellite images, and was still present in the 2015, 2016 and 2017 satellite images. This colony was not present in 1962 (Bauer 1963) or during ground observations in 1974 and 1982 (Derenne et al. 1976, Voisin 1984). It was not mentioned in 1988, but the Spot images focused on the Morne du Tamaris colony (Guinet et al. 1995). However, the size of this new colony (17000 pairs) can account for the relocation of only a small fraction of the original colony.

Third, feral cats (Felis catus L.) and house mice (Mus musculus L.) are present on Ile aux Cochons (Derenne \& Mougin 1976, Derenne et al. 1976). Cats apparently occurred in small numbers in the 1970s (Derenne et al. 1976) and neither species is known to be a predator of king penguin chicks. However, the behaviour of these two introduced species towards native fauna has changed during recent years on other sub-Antarctic islands, as shown by observations on Gough and Marion islands of mice attacking albatross chicks, causing the decline of at least some populations (Wanless et al. 2007, Davies et al. 2015, Dilley et al. 2016), or at Kerguelen, where cats have been observed to attack wandering albatross (Diomedea exulans $\mathrm{L}$.) chicks, reducing breeding success (Weimerskirch unpublished data).

Fourth, diseases or parasites can seriously affect seabird populations, reducing breeding success, survival of adults and population growth rates (Weimerskirch 2004, Cooper et al. 2009). There are no data available about the occurrence of any such diseases on Ile aux Cochons. Tick infestations also affect seabird populations, and have been found to be a vector of Lyme disease in king penguins (Gauthier-Clerc et al. 1999), but again a massive tick infestation appears to be unlikely compared to the situation recorded on Ile de la Possession. The extent of the decrease of the colony of Morne du Tamaris would be unprecedented if it were a result of disease outbreak, but previous large mortalities of king penguins (although not to the same extent as in the Ile aux Cochons colony) have been reported in 1992-1993 on Marion Island (Cooper et al. 2009), at the time of the rapid decline described here.

Finally, a catastrophic event seems unlikely to have occurred. The colony is well inland and therefore should not be impacted by a tsunami, and there is no evidence of a volcanic eruption on the satellite images or recent helicopter photographs. Furthermore, the progressive decline of the extent of the colony suggests a gradual, long-term decrease in this colony.

In conclusion, the cause of the massive decline of the colony remains a mystery, and needs to be resolved. Although the decline started at least 20 years ago, it appears to be ongoing, and the causes of the decline may 
still be active. Ile aux Cochons is rarely visited, and the use of satellite images has allowed the detection of this unexpected phenomenon. However, to be able to understand the cause of the decline, it is necessary to study the colony on land and at sea. The last visits ashore were in 1974 and 1982. It would be of considerable importance to examine the foraging ecology (including at-sea distribution) of individuals from this colony to detect potential adverse trophic conditions, and make observations on the conditions that occur on land today, such as the possible presence of diseases and parasites, and the effects of native or introduced predators.

\section{Acknowledgements}

This study was funded by the French Polar Institute (Program IPEV 109), by Réserve Nationale des Terres Australes Françaises), and by ACE, a scientific expedition carried out under the auspices of the Swiss Polar Institute, supported by funding from the ACE Foundation and Ferring Pharmaceuticals. We thank the crews and especially the helicopter pilots for their help, Joris Laborie and Adrien Chaigne for help with QGIS and two anonymous referees for comments on the manuscript.

\section{Author contributions}

HW oversaw the project, analysed satellite images, and wrote a first draft of the manuscript. PGR and FLB analysed the aerial photographs from the colony during the ACE cruise and estimated the population size from the photographs. All authors contributed to the overall editing and organization of the manuscript.

\section{References}

Barrat, A. 1976. Quelques aspects de la biologie et de l'écologie du manchot royal (Aptenodyptes patagonicus) des iles Crozet. CNFRA, 40, 9-52.

Bauer, A. 1963. Dénobrement des manchotieres de l'Ile aux Cochons (Archipel des Crozet) et de l'Ile de Kerguelen. TAAF, 25, 35-39.

Bauer, A. 1967. Denombrement des manchotieres de l'archipel des crozet et des iles Kerguelen a l'aide de photographies aeriennes verticales. TAAF, 41, 3-21.

Boersma, P.D. \& Borboroglu, P.G. 2013. Penguins. Natural history and conservation. Seattle: University of Washinton Press, $365 \mathrm{pp}$.

Bost, C.A., Cotté, C., Terray, P., Barbraud, C., Bon, C., Delord, K., Gimenez, O., Handrich, Y., Naito, Y., Guinet, C. \& Weimerskirch, H. 2015. Large-scale climatic anomalies affect marine predator foraging behaviour and demography. Nature Communications, 6, doi: $10.1038 /$ ncomms 9220 .

Convey, A., Morton, A. \& Poncet, J. 1999. Survey of marine birds and mammals of the South Sandwich Islands. Polar Record, 35, doi: $10.1017 / \mathrm{S} 0032247400026450$.

Cooper, J., Crawford, R.J.M., De Villiers, M.S., Dyer, B.M., Hofmeyr, G.J.G. \& Jonker, A. 2009. Disease outbreaks among penguins at sub-Antarctic Marion Island: a conservation concern. Marine Ornithology, 37, 193-196.
Crawford, R.J.M., Whittington, P.A., Upfold, L., Ryan, P.G., Petersen, S.L., Dyer, B.M. \& Cooper, J. 2009. Recent trends in numbers of four species of penguins at the Prince Edward Islands. African Journal of Marine Science, 31, doi: 10.2989/ AJMS.2009.31.3.14.1002.

Davies, D., Dilley, B.J., Bond, A.L., Cuthbert, R.J. \& Ryan, P.G. 2015. Trends and tactics of mouse predation on Tristan Albatross Diomedea dabbenena chicks at Gough Island, South Atlantic Ocean. Avian Conservation and Ecology, 10, doi: 10.5751/ACE-00738-100105.

Delord, K., Barbraud, C. \& Weimerskirch, H. 2004. Long-term trends in the population size of king penguins at Crozet archipelago: environmental variability and density dependence? Polar Biology, 27, doi: 10.1007/s00300-004-0651-z.

Derenne, P. \& Mougin, J.L. 1976. Données craniométriques sur le Lapin et le Chat haret de l'île aux Cochons, Archipel Crozet (46 $06^{\prime} \mathrm{S}$, 50¹4' E). Mammalia, 40, doi: 10.1515/mamm.1976.40.3.495.

Derenne, P., Mougin, J.L., Steinberg, C. \& Voisin, J.F. 1976. Les oiseaux de l'ile aux Cochons, archipel Crozet. CNFRA, 40, 107-148.

Descamp, S., Gauthier-Clerc, M., Gendner, J.P. \& Le Maho, Y. 2002. The annual breeding cycle of unbanded king penguins (Aptenodytes patagonicus) on Possession Island (Crozet). Avian Science, 2, 87-98.

Dilley, B.J., Schoombie, S., Schoombie, J. \& Ryan, P.G. 2016. 'Scalping' of albatross fledglings by introduced mice spreads rapidly at Marion Island. Antarctic Science, 28, doi: 10.1017/ S0954102015000486.

Fretwell, P.T., LaRue, M.A., Morin, P., Kooyman, G.L., Wienecke, B., Ratcliffe, N., Fox, A.J., Fleming, A.H., Porter, C. \& Trathan, P.N. 2012. An emperor penguin population estimate: the global, synoptic survey of a species from space. PLoS ONE, 7, e33751.

Fretwell, P.T. \& Trathan, P.N. 2009. Penguins from space: faecal stains reveal the location of emperor penguin colonies. Global Ecology and Biogeography, 18, doi: 10.1111/j.1466-8238.2009.00467.x.

Gauthier-Clerc, M., Jauhlac, B., Frenot, Y., Bachelard, C., Monteil, H., Le Maho, Y. \& Handrich, Y. 1999. Prevalence of Borrelia burgdorferi (the Lyme disease agent) antibodies in king penguins. Polar Biology, 22, 141-143.

Guinet, C., Cherel, Y., Ridoux, V. \& Jouventin, P. 1996. Consumption of marine resources by seabirds and seals in Crozet and Kerguelen waters: changes in relation to consumer biomass 1962 85. Antarctic Science, 8, doi: 10.1017/S0954102096000053.

Guinet, C., Jouventin, P. \& Malacamp, J. 1995. Satellite remote sensing in monitoring change of seabirds: use of spot image in king penguin population increase at Ile aux Cochons, Crozet Archipelago. Polar Biology, 15, 511-515.

LaRue, M.A., Lynch, H.J., Lyver, P.O.B., Barton, K., Ainley, D.G., Pollard, A., Fraser, W.R. \& Ballard, G. 2014. A method for estimating colony sizes of Adélie penguins using remote sensing imagery. Polar Biology, 37, 507-517.

Le Bohec, C., Durant, J.M., Gauthier-Clerc, M., Stenseth, N.C., Park, J.H., Pradel, R., Grémillet, D., Gendner, J.P. \& LeMaho, Y. 2008. King penguin population threatened by Southern Ocean warming. Proceedings of the National Academy of Sciences, 105, doi: 10.1073/pnas.0712031105.

Pistorius, P., Hindell, M.A., Crawford, R.M., Makhado, A., Dyer, B. \& ReIsinger, R. 2017. At-sea distribution and habitat use in king penguins at sub-Antarctic Marion Island. Ecology and Evolution, 7, doi: 10.1002/ece3.2833.

Rounsewell, D.E. \& Copson, G.R. 1982. Growth rate of a king penguin Aptenodytes patagonicus population after exploitation. Australian Wildlife Research, 9, doi: 10.1071/WR9820519.

Saraux, C., Viblanc, V.A., Hanuise, N., Le Maho, Y. \& Le Bohec, C. 2011. Effects of individual pre-fledging traits and environmental conditions on return patterns in juvenile king penguins. PLOS ONE, 6 , e20407. 
SANDERS, S. 2006. Important bird areas in the United Kingdom overseas territories. Sandy: Royal Society for the Protection of Birds, $284 \mathrm{pp}$.

Scheffer, A., Bost, C.A. \& Trathan, P. 2012. Frontal zones, temperature gradient and depth characterize the foraging habitat of king penguins at South Georgia. Marine Ecology Progress Series, $\mathbf{4 6 5}$, doi: 10.3354/meps09884.

VoIsIn, J.F. 1984. Observations on the birds and mammals of Ile aux Cochons, Crozet Islands, in February 1982. South African Journal of Antarctic Research, 14, 11-17.
Wanless, R.M., Angel, A., Cuthbert, R.J., Hilton, G.M. \& Ryan, P.G. 2007. Can predation by introduced mice drive seabird extinctions? Biology Letters, 3, doi: 10.1098/rsbl.2007.0120.

WeImerskirch, H. 2004. Diseases threaten Southern Ocean albatrosses. Polar Biology, 27, 374-379.

Weimerskirch, H., Stahl, J.C. \& Jouventin, P. 1992. The breeding biology and population dynamics of king penguins Aptenodytes patagonica on the Crozet Islands. Ibis, 134, doi: 10.1111/j.1474-919X.1992.tb08387.x.

Weimerskirch, H., Zotier, R. \& Jouventin, P. 1989. The avifauna of the Kerguelen Islands. Emu, 89, doi: 10.1071/MU9890015. 